\title{
The Perception of Parents and Guardians in Abakaliki - Nigeria towards the Total Abolition of Paper and Pencil Test (PPT) in the Unified Tertiary Matriculation Examinations (UTME)
}

\author{
Fergus U. Onu (Ph.D) \\ Department of Computer Science, Ebonyi State University, Abakaliki - Nigeria
}

\begin{abstract}
The essence of any assessment system is to reveal the actual knowledge of the candidate in the subject being assessed. If the system is faulty, the result of the assessment will be unreliable. This paper examines the introduction of information technology (IT) into the Unified Tertiary Matriculation Examination (UTME) assessment system as a major step towards the improvement of Nigerian educational assessment system. The research through a primary source of data from 250 respondents in Abakaliki Area deduced that the full introduction of the CBT system into the UTME was a major step towards the full utilization of IT in education. That summarily introduced the benefits of speed, reduction in all forms of examination malpractices and general efficiency into the UTME assessment system in particular and tertiary education system in general. The research revealed that parents and guardians some of who were university staff were of the opinion that CBT system should be extended to the general courses in tertiary institutions in Nigeria.
\end{abstract}

Keywords: eAssessment, Tertiary Education, OMR, PPT, CBT

\section{Introduction}

Education and training are the sure ways to ensure steady and sustained development of individuals, communities and nations. To ensure effective education system, the assessment methods as part of the system must be effective as well as efficient. In Nigeria, the primary and secondary schools were meant to form the foundation for quality and functional education system, while the tertiary education goes ahead to build specialised skills into the students. Normally, not everyone who finished primary school goes into secondary school. Similarly, not every person who graduated from a secondary school continues to the tertiary institutions. The reasons behind the suspension of training at different levels could be any of: (1) lack of fund, (2) failure in entrance examinations/ assessments, (3) lack of support (financial or/and moral), (4) lack of interest to continue, peer preasure. Just to mention but a few.

The entrance into tertiary institutions in Nigeria has been organised and managed by the Joint Admission and Matriculation Board (JAMB). According to [1] JAMB is a body established by the Act No. 2 of 1978 of the Federal Military Government on $13^{\text {th }}$ February, 1978. The act was later amended by section 5 of decree 33 of 1989 . In the words of [2], the Decree 33 of 1989 expanded the scope of operations of JAMB to cover Monotechnics, Polytechnics and Colleges of education by whatever name they are called in Nigeria. The enabling Decree also empowered the Board to monitor and describe admission practices into all higher institutions in Nigeria. The Board from inception was charged with the following functions:

1) General control of the matriculation examination for admissions into all universities, polytechnics and colleges of education in Nigeria.

2) Appointment of examiners, moderators, invigilators,
3) Appointment of members of the subjects panel, committees and other persons with respect to Matriculation Examinations

4) Any other maters incidental to or connected with the Matriculation Examinations

5) Placing suitably qualified candidates in the tertiary institutions.

With these functions, [1] stated that the Board conducted the Monotechnics, Polytechnics and Colleges of Education Matriculation Examination (MPCEME) alongside the Universities Matriculation Examination (UME) from 1989 till the year 2009. In 2010 and in pursuance of the Roadmap for the rebranding and repositioning of the education sector by the Federal Ministry of Education, JAMB merged the MPCEME and UME to form the Unified Tertiary Matriculation Examination (UTME) [1]. Since 2010, JAMB conducts UTME every year and forwards the results to the candidates' institutions of choice for selection and admission. Over the years, the UTME by JAMB had been in a Paper and Pencil Test (PPT) form, and was characterized by a lot of fraudulent practices ranging from leakage of examination papers, use of machineries of all sorts by candidates, bribe taking by examination officials, impersonation, use of unauthorized gadgets, and so on [3].

Many countries have accepted the adoption of technology into their educational system inorder to improve teaching, learning and by extension assessment. According [4] Nigeria, is one of those countries that are reforming their education policies using ICT and adopting the computer based examination system in its institutions of higher education. In the opinion of [5], ICT was revolutionalizing education in Nigeria by removing distance and making knowledge more available to all. Similarly, [6] posited that the growth of Internet had largely changed teaching and learning from a conventional class room into an invaluable 


\section{International Journal of Science and Research (IJSR) \\ ISSN (Online): 2319-7064 \\ Index Copernicus Value (2013): 6.14 | Impact Factor (2014): 5.611}

educational resource accessible remotely from disperse geographical locations, beyond physical boundaries.

In 2013, JAMB introduced the computer based testing (CBT) form of UTME and gave it massive publicity and sensitization in order to reduce the incidence of the vices observed in the PPT form of the UTME to its bearest minimum. To avoid a total disencfranchisement of students who may claim that they do not have computer literacy skills from writing the 2013 UTME, JAMB conducted the 2013 edition of the Unified Tertiary Matriculation Examination (UTME) with three test options namely:- the traditional PPT, Dual-Based Test (DBT) and CBT. While assessing the DBT and CBT which were novel introductions at that moment, [7] reported that the systems were largely successful in spite of some challenges especially in the area of infrastructure.

In 2015, the PPT and DBT were completely faced out and the entire UTME was taken using the CBT form. The Executive Registrar of JAMB, Professor Dibu Ojerinde, announced that the objectives of the e-testing system was to ensure 100 percent elimination of all forms of examination malpractices that had been a major challenge in the conduct of public examinations in the country [8]. The CBT system among other features includes a biometric authentication system ment to fight any attempt to impersonate.

Considering the reasons for the adoption of the CBT for UTME on one hand, the success so far recorded and the wide acceptance of the assessment system on the other, it is therefore necessary to take the use of information technology in in education to the next level. This next level has to be determined by the tertiary institutions' administrators, students and parents/guardians.

\section{Some Terms Explained}

\section{Assessment Defined}

Many authors and writers have given the word "assessment" a lot of definitions. Assessment activity ranges from grading student course assignments, to standardized testing imposed on institutions as part of increased pressure for external accountability. It also referes to any activity designed to collect information on the success of a program, course, or University curriculum. There are varied uses of assessment. The essence of any assessment is to gather information to improve institutional practices. Following that ascertion, [1] defined assessment as the systematic collection and analysis of information to improve student learning. According to [9] assessment is not a one-point activity it is an ongoing process that involves planning, discussion, consensus building, reflection, measuring, analyzing, and improving based on the data and artifacts gathered about a learning objective.

\section{Types of Assessment}

Assessment can be performance based or traditional [10]. [5] presented summative and formative assessments. Some other sources presented formative, interim and summative assessments. [10] and [11] specified formal, informal and performance-based assessments methods. We wish to add that there are oral or presentation and written or paper-based assessments. Both types of assessments are necessary depending on the purpose of the assessment. Presentation assessment may not be suitable in cases where written assessments are needed and vise versa. Written and/or oral assessments can be done using electronic/digital gardgets or devices in which case it is called Electronic Assessment (eAssessment). eAssessment is defined in its broadest sense as a situation where information technology is used for any assessment-related activity [11]. In some cases the paper and pencil and electronic methods can be combined to give the dual/hybride assessment method. That was what JAMB adopted as Dual Based Test.

\section{Purposes of Assessment}

The reasons for an assessment vary considerably across many groups of people. Assessment may affect decisions about grades, advancement, placement, instructional needs, and curriculum [8]. Assessment provides an accurate measure of assessee performance to enable teachers, administrators, and other key decision makers (like parents, guardians and students) to make effective decisions [12]. Table 1 shows different assessors and the purposes for which they may carry out an assessment.

Table 1: Purposes of Assessment to different stakeholders

\begin{tabular}{|c|c|}
\hline Assessor & Purposes of Assessment \\
\hline \multirow[t]{8}{*}{ Policymakers } & Policymakers use assessment to: \\
\hline & * Set standards \\
\hline & * Focus on goals \\
\hline & * Monitor the quality of education \\
\hline & * Reward/sanction various practices \\
\hline & * Formulate policies \\
\hline & * Direct resources including personnel and money \\
\hline & * Determine effects of tests \\
\hline \multirow[t]{5}{*}{$\begin{array}{l}\text { Administrators } \\
\text { and school }\end{array}$} & $\begin{array}{l}\text { Monitor program effectiveness planners use } \\
\text { assessment to: }\end{array}$ \\
\hline & * Identify program strengths and weaknesses \\
\hline & * Designate program priorities \\
\hline & * Assess alternatives \\
\hline & * Plan and improve programs \\
\hline \multirow{7}{*}{$\begin{array}{l}\text { Teachers and } \\
\text { administrators }\end{array}$} & Make grouping decisions use assessment to: \\
\hline & * Perform individual diagnosis and prescription \\
\hline & * Monitor student progress \\
\hline & * Carry out curriculum evaluation and refinement \\
\hline & $\begin{array}{l}\text { * Provide mastery/promotion/grading and other } \\
\text { feedback }\end{array}$ \\
\hline & * Motivate students \\
\hline & * Determine grades \\
\hline
\end{tabular}

Adapted from [12]

\section{Challenges to Assessments}

Every form of assessment whether paper-based or electronic has its own challenges. The paper-based assessments are prone to all forms of examination malpractices as list by [3]. On the other hand the eAssessment method have security and integrity issues to worry about. According to [13] the user can compromise security consciously or unconsciously and that act may affect the integrity of the test result.

\section{Volume 4 Issue 11, November 2015}




\section{International Journal of Science and Research (IJSR) \\ ISSN (Online): 2319-7064}

Index Copernicus Value (2013): 6.14 | Impact Factor (2014): 5.611

Principles of Good Assessment Practice

Effective assessment begins with clear goals [12]. Assessment practices are essentially expected to be practically achievable and functionally effective. [1] has summarized principles of good assessment practice as listed in table 2 below:

Table 2: Principles of good assessment practice

\begin{tabular}{|l|}
\hline S/n Principles of good assessment practice \\
\hline 1)Assessment begins with educational values. \\
\hline $\begin{array}{l}\text { 2) Assessment is most effective when it is multidimensional, } \\
\text { integrated, and revealed in performance over time. }\end{array}$ \\
\hline $\begin{array}{l}\text { 3)Assessment works best when the programs it seeks to } \\
\text { improve have clear, explicitly stated purposes. }\end{array}$ \\
\hline $\begin{array}{l}\text { 4)Assessment requires attention to outcomes but also and } \\
\text { equally to the experiences that lead to those outcomes. }\end{array}$ \\
\hline 5)Assessment works best when it is ongoing not episodic. \\
\hline $\begin{array}{l}\text { 6) Assessment fosters wider improvement when representatives } \\
\text { from across the educational community are involved. }\end{array}$ \\
\hline $\begin{array}{l}\text { 7) Assessment makes a difference when it illuminates questions } \\
\text { that people really care about. }\end{array}$ \\
\hline $\begin{array}{l}\text { 8)Assessment is most likely to lead to improvement when it is } \\
\text { part of a larger set of conditions that promote change. }\end{array}$ \\
\hline $\begin{array}{l}\text { 9)Through assessment, educators meet responsibilities to } \\
\text { students and to the public. }\end{array}$ \\
\hline
\end{tabular}

Adapted from [1]

\section{Methodology}

The research used primary source of data which was collected with a structured set of questionnaire validated and administered to 250 respondents in Abakaliki area of Ebonyi State Nigeria. These respondents were mainly parents and guardians whose wards have been involved in UTME at one time or the other. The responses were subsequently presented and analysed on the 5-point linkert scale type. The data collected from the primary source were analysed and presented below.

\section{Data Presentation, Analysis and Results}

Gender distribution of respondents: Table 3 shows the gender distribution of the respondents. Here we noticed that out of the 250 respondents whose opinions were sort, 190 i.e. $76 \%$ were male while 60 i.e. $24 \%$ were female. That was more clearly and graphically shown in figure 1 .

Table 3: Gender distribution of respondents

\begin{tabular}{|l|c|c|}
\hline Gender & No. of respondents & Percentage \\
\hline Male & 190 & $76 \%$ \\
\hline Female & 60 & $24 \%$ \\
\hline Total & 250 & $100 \%$ \\
\hline
\end{tabular}

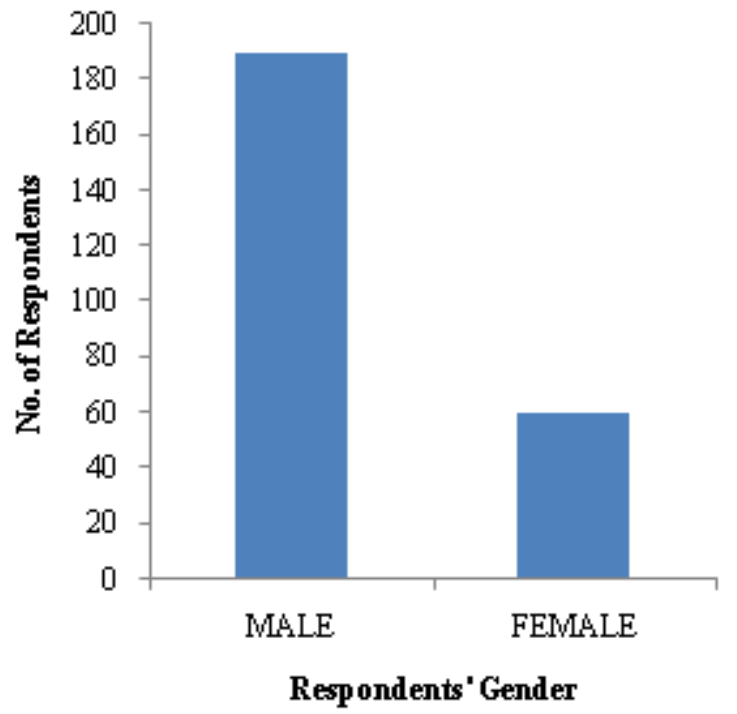

Figure 1: Gender distribution of the respondents

Age distribution of respondents: Table 4 shows the representation of the age distribution of the repondents. $8 \%$ of the respondents were between the ages of 20 to 25 years. $20 \%$ were between 26 to 30 years of age. While greater number $60 \%$ of the respondents were 31 to 40 years of age. Respondents above 40 years of age accounted for $12 \%$ of the entire population. The spread in the age of the respondents showed that respondents were mainly parents/guardian some of whom were staff of tertiary institutions. Figure 2 shows the graphical representation of the age distribution of the respondents.

Table 4: Age distribution of respondents

\begin{tabular}{|l|c|c|}
\hline Age (years) & No. of respondents & Percentage \\
\hline Below 20 & 0 & $00 \%$ \\
\hline $20-25$ & 20 & $8 \%$ \\
\hline $26-30$ & 50 & $20 \%$ \\
\hline $31-40$ & 150 & $60 \%$ \\
\hline Above 40 & 30 & $12 \%$ \\
\hline
\end{tabular}

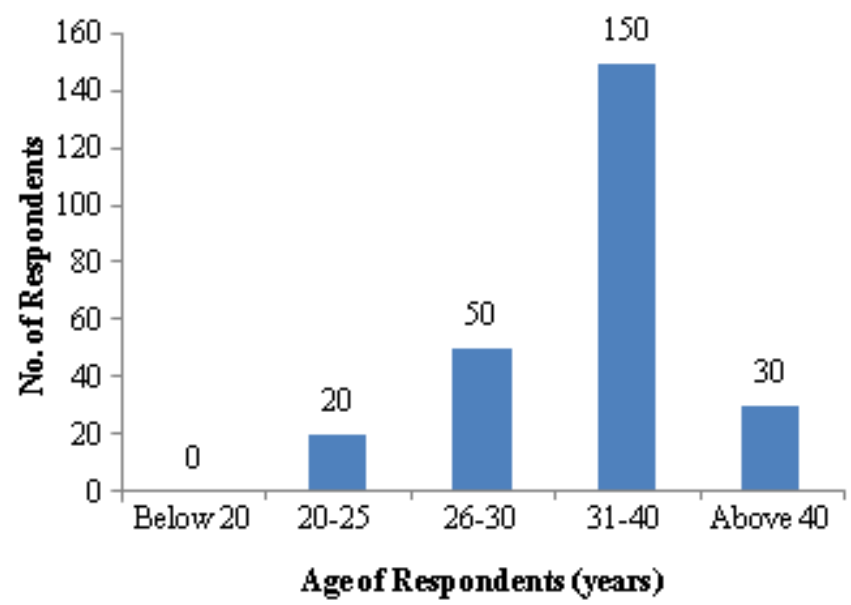

Figure 2: Age distribution of respondents

Employment/Social status of respondents: Table 5 shows the respondents' employment/social status. 160 respondents i.e $96 \%$ were parents/guardians some of whom i.e. $32 \%$ were university staff. the remaining $4 \%$ were jamb candidates. The graphical representation of the data is shown in the pie chart in figure 3 .

\section{Volume 4 Issue 11, November 2015}




\section{International Journal of Science and Research (IJSR) \\ ISSN (Online): 2319-7064 \\ Index Copernicus Value (2013): 6.14 | Impact Factor (2014): 5.611}

Table 5: Employment/Social status of respondents

\begin{tabular}{|l|c|c|}
\hline \multicolumn{1}{|c|}{ Status } & No. of respondents & Percentage \\
\hline Parent/Guardian & 160 & $64 \%$ \\
\hline University staff & 80 & $32 \%$ \\
\hline Jambites & 10 & $4 \%$ \\
\hline
\end{tabular}

Analysis of respondents' choices: Table 6 shows the representation of the choices of the repondents to the various questions posed by the interviewer while assessing the perception of the parents and guardians towards the introduction of CBT by JAMB.

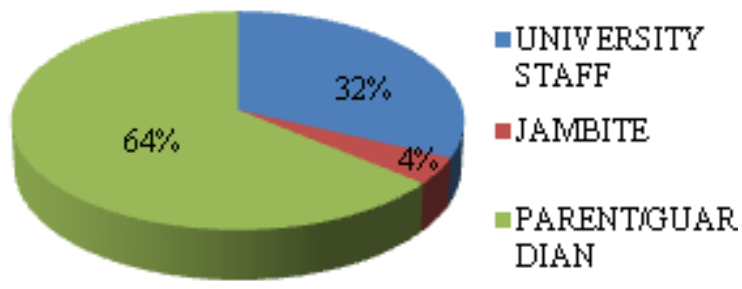

Figure 3: Employment/social status of respondents

Table 6: Respondents' opinion on statements concerning the use of CBT for UTME in Nigeria

\begin{tabular}{|c|c|c|c|c|c|c|}
\hline $\mathbf{S} / \mathbf{N}$ & Statement & $x$ & $\mathbf{F}$ & $f \times$ & $\bar{x}$ & $\% f$ \\
\hline 1 & \multicolumn{6}{|c|}{ The introduction of CBT by JAMB is a welcome development. } \\
\hline & Strongly Agree & 5 & 160 & 800 & \multirow{5}{*}{4.4} & $64 \%$ \\
\hline & Agree & 4 & 70 & 280 & & $28 \%$ \\
\hline & Don't Know & 3 & 0 & 0 & & $0 \%$ \\
\hline & Disagree & 2 & 0 & 0 & & $0 \%$ \\
\hline & Strongly Disagree & 1 & 20 & 20 & & $8 \%$ \\
\hline \multirow[t]{6}{*}{2} & \multicolumn{6}{|c|}{$\begin{array}{l}\text { A lot of jambites do not know how to use computer, so CBT } \\
\text { will pose a hinderance to their good performance in the UTME }\end{array}$} \\
\hline & Strongly Agree & 5 & 120 & 600 & \multirow[t]{5}{*}{4.24} & $48 \%$ \\
\hline & Agree & 4 & 100 & 400 & & $40 \%$ \\
\hline & Don't Know & 3 & 10 & 30 & & $4 \%$ \\
\hline & Disagree & 2 & 10 & 20 & & $4 \%$ \\
\hline & Strongly Disagree & 1 & 10 & 10 & & $4 \%$ \\
\hline \multicolumn{7}{|c|}{ techn } \\
\hline & Strongly Agree & 5 & 40 & 200 & \multirow[t]{5}{*}{2.92} & $16 \%$ \\
\hline & Agree & 4 & 60 & 240 & & $24 \%$ \\
\hline & Don't Know & 3 & 40 & 120 & & $16 \%$ \\
\hline & Disagree & 2 & 60 & 120 & & $24 \%$ \\
\hline & Strongly Disagree & 1 & 50 & 50 & & $20 \%$ \\
\hline 4 & \multicolumn{6}{|c|}{$\begin{array}{l}\text { CBT system is more prone to examination paper leakage than } \\
\text { the Paper and Pencil (PPT) system }\end{array}$} \\
\hline
\end{tabular}

\begin{tabular}{|c|c|c|c|c|c|c|}
\hline & Strongly Agree & 5 & 20 & 100 & \multirow{5}{*}{2.04} & $8 \%$ \\
\hline & Agree & 4 & 20 & 80 & & $8 \%$ \\
\hline & Don't Know & 3 & 20 & 60 & & $8 \%$ \\
\hline & Disagree & 2 & 80 & 160 & & $32 \%$ \\
\hline & Strongly Disagree & 1 & 110 & 110 & & $44 \%$ \\
\hline \multirow[t]{6}{*}{5} & $\begin{array}{l}\text { The use of CBT in } \\
\text { especially in exami }\end{array}$ & ion & $\begin{array}{l}\text { makes } \\
\text { radin }\end{array}$ & $\begin{array}{l}\text { he proc } \\
\text { and res }\end{array}$ & s ver & \\
\hline & Strongly Agree & 5 & 230 & 1150 & \multirow{5}{*}{4.92} & $92 \%$ \\
\hline & Agree & 4 & 20 & 80 & & $8 \%$ \\
\hline & Don't Know & 3 & 0 & 0 & & $0 \%$ \\
\hline & Disagree & 2 & 0 & 0 & & $0 \%$ \\
\hline & Strongly Disagree & 1 & 0 & 0 & & $0 \%$ \\
\hline \multirow[t]{6}{*}{6} & $\begin{array}{l}\text { The use of CBT red } \\
\text { malpractices consid }\end{array}$ & es. & $\begin{array}{l}\text { perso } \\
\text { and sh }\end{array}$ & $\begin{array}{l}\text { tion ar } \\
\text { ld be }\end{array}$ & $\begin{array}{l}\text { other } \\
\text { coura }\end{array}$ & mination \\
\hline & Strongly Agree & 5 & 180 & 900 & \multirow[t]{5}{*}{4.6} & $72 \%$ \\
\hline & Agree & 4 & 60 & 240 & & $24 \%$ \\
\hline & Don't Know & 3 & 0 & 0 & & $0 \%$ \\
\hline & Disagree & 2 & 0 & 0 & & $0 \%$ \\
\hline & Strongly Disagree & 1 & 10 & 10 & & $4 \%$ \\
\hline \multirow[t]{6}{*}{7} & $\begin{array}{l}\text { CBT system does } n \\
\text { alotted for the test }\end{array}$ & all & $\begin{array}{l}\text { cand } \\
\text { termi }\end{array}$ & $\begin{array}{l}\text { ates to } \\
\text { at com }\end{array}$ & $\begin{array}{l}\text { se all } \\
\text { iter sy }\end{array}$ & $\begin{array}{l}\text { ime } \\
\text { n failures }\end{array}$ \\
\hline & Strongly Agree & 5 & 40 & 200 & \multirow[t]{5}{*}{3.32} & $16 \%$ \\
\hline & Agree & 4 & 80 & 320 & & $32 \%$ \\
\hline & Don't Know & 3 & 60 & 180 & & $24 \%$ \\
\hline & Disagree & 2 & 60 & 120 & & $24 \%$ \\
\hline & Strongly Disagree & 1 & 10 & 10 & & $4 \%$ \\
\hline \multirow[t]{6}{*}{8} & $\begin{array}{l}\text { CBT system will lil } \\
\text { miracle centres in J }\end{array}$ & & $\begin{array}{l}\text { ninate } \\
\text { nd oth }\end{array}$ & $\begin{array}{l}\text { he pres } \\
\text { entera }\end{array}$ & $\begin{array}{l}\text { ice an } \\
\text { ce exa }\end{array}$ & $\begin{array}{l}\text { actise of } \\
\text { ations }\end{array}$ \\
\hline & Strongly Agree & 5 & 150 & 750 & \multirow[t]{5}{*}{4.24} & $60 \%$ \\
\hline & Agree & 4 & 50 & 200 & & $20 \%$ \\
\hline & Don't Know & 3 & 30 & 90 & & $12 \%$ \\
\hline & Disagree & 2 & 0 & 0 & & $0 \%$ \\
\hline & Strongly Disagree & 1 & 20 & 20 & & $8 \%$ \\
\hline \multirow[t]{6}{*}{9} & $\begin{array}{l}\text { JAMB should neve } \\
\text { CBT for their asses }\end{array}$ & & of goi & back t & any th & less than \\
\hline & Strongly Agree & 5 & 190 & 950 & \multirow[t]{5}{*}{4.52} & $76 \%$ \\
\hline & Agree & 4 & 20 & 80 & & $8 \%$ \\
\hline & Don't Know & 3 & 20 & 60 & & $8 \%$ \\
\hline & Disagree & 2 & 20 & 40 & & $8 \%$ \\
\hline & Strongly Disagree & 1 & 0 & 0 & & $0 \%$ \\
\hline \multirow[t]{6}{*}{10} & $\begin{array}{l}\text { The CBT system sh } \\
\text { tertiary institutions } \\
\text { use }\end{array}$ & & $\begin{array}{l}\text { exter } \\
\text { ly wh }\end{array}$ & e to $\mathrm{OM}$ & gener & $\begin{array}{l}\text { ourses in } \\
\text { already in }\end{array}$ \\
\hline & Strongly Agree & 5 & 70 & 350 & \multirow[t]{5}{*}{3.4} & $28 \%$ \\
\hline & Agree & 4 & 70 & 280 & & $28 \%$ \\
\hline & Don't Know & 3 & 40 & 120 & & $16 \%$ \\
\hline & Disagree & 2 & 30 & 60 & & $12 \%$ \\
\hline & Strongly Disagree & 1 & 40 & 40 & & $16 \%$ \\
\hline
\end{tabular}




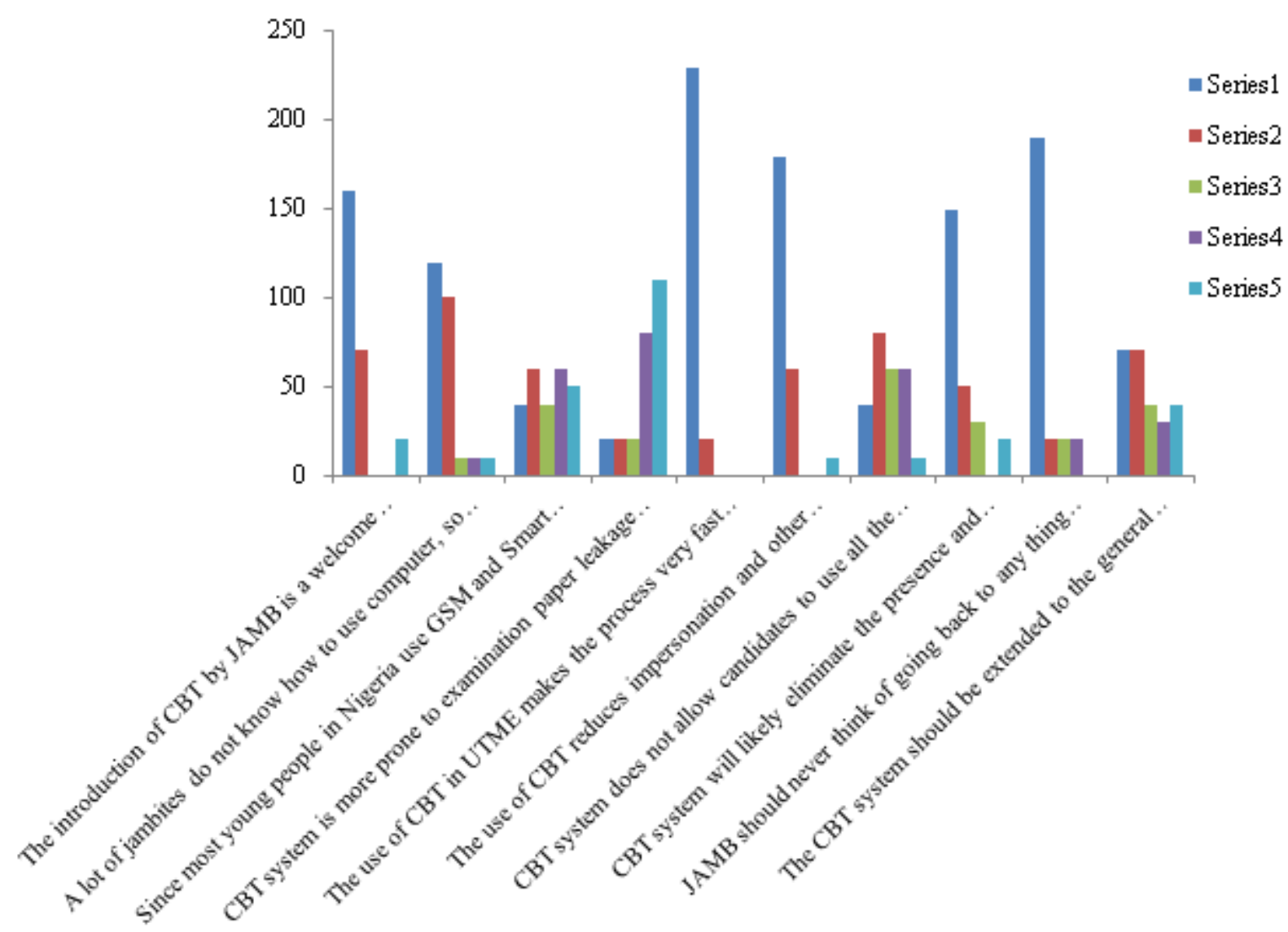

Figure 5: Graph of respondents' opinion on questions about CBT

\section{Discussion}

The research revealed that though most young people in Nigeria use GSM and Smart phones, it should not be assumed that they were already farmiliar with computer based technology deployed for CBT. Greater than half of the respondents expressed the fear that intermittent computer system and power failures would interfer with and hinder the candidates from using the full time allotted for the subjects during the eaminations. Parents and guardians were skeptical about CBT, they thought that a lot of UTME candidates do not know how to use computer and so CBT would pose a hinderance to their good performance in the examination. These fears were addressed by the general performance of candidates in 2015/2016 UTME which was the first adoption of CBT. The candidates in Abakaliki area generally preferred CBT over any of PPT and DBT.

The above revelations notwithstanding, the research showed that $92 \%$ of the respondents who were parents and guardians overwhejmingly welcomed the introduction of CBT by JAMB. More still, $100 \%$ of the respondents including UTME candidates believed that the use of CBT in UTME makes the process very fast especially in examination grading and result publication. That was a very important revelation noting that any delays in result publication can introduce inefficiency into the assessment system. That also agreed with the report of the 2015/2016 UTME.

Regarding examination paper leakage and other examination malpractices which have be-deviled the assessment systems in Nigeria, $100 \%$ of the respondents were of the opinion that CBT can deliver a malpractice (especially impersonation) free examination due to the deployment of full biometric authetication system. In the same manner $80 \%$ of the respondents believe that $\mathrm{CBT}$ will eliminate the practise of miracle centers in other examinations similar to the UTME.

In the opinion of the respondents, reverting back to earlier forms of assessment for UTME i.e. PPT or DBT, $84 \%$ of the respondents felt that JAMB should never think of turning back from CBT. Instead of turning back, $56 \%$ of the respondents were of the opinion that CBT should be extended to the general courses in tertiary institutions especially where (Optical Mark Recorgnition) OMR system were already in use. That would reduce cost(in form of human resources deployed into the examination administration) and will increase the speed of examination grading and result publication.

\section{Conclusion}

Now that we have seen the positive perception of the parents and guardians towards the introduction of CBT into UTME, we conclude by suggesting that the gains of speed, prevention of impersonation, examination paper leakage, and other forms of examination malpractices be extended to the general courses in the tertiary institutions. This can only be done by introducing CBT into these general courses. Since most tertiary institution are already are already using OMR system to examine their general courses, the management of the tertiary institutions have nothing (absolutely nothing) to loose by introducing CBT. This would rather be the next step into the full deployment of ICT in Education. 


\section{International Journal of Science and Research (IJSR) \\ ISSN (Online): 2319-7064}

Index Copernicus Value (2013): 6.14 | Impact Factor (2014): 5.611

\section{References}

[1] Independent Advocate (2013) Why was JAMB established, Online at http://www.nigerianelitesforum.com/ng/youthseducation-scholarships/38572-history-of-jamb.html retrieved July 22nd, 2015

[2] Ojerinde D. and Ojo F. (2014), The policy, practice, problems and prospects of the unified tertiary matriculation examination (UTME) in Nigeria. JAMB abuja

[3] Joshua T. M, Joshua M. A and Ikiroma B. (2014) Computer-based testing in Nigeria's University entrants' matriculation examination: readiness and acceptability of critical stake-holders online at ... retrieved July $22^{\text {nd }}, 2015$.

[4] Angelo A. T. and Cross P. K (2010) Classroom Assessment Techniques: A Handbook for College Teachers, 2nd edition

[5] Ugah J. O. and Onu F. U. (2013): The impact of EAssessment on Educational Systems in Nigeria. African journal of physical sciences ISSN: 2141 - 0100; volume 6, number 2, Pp 60-68. Davon Science Company, Enugu - Nigeria.

[6] Gathuri W. J., Luvanda A., Matende S., and Kamundi S. (2014): Impersonation Challenges Associated With EAssessment of University Students. Journal of Information Engineering and Applications ISSN 22245782 (print) ISSN 2225-0506 (online) Vol.4, No.7, 2014 URL: www.iiste.org

[7] Abubakar S. A. and Adebayo O. F. (2014), Using Computer Based Test Method for the Conduct of Examination in Nigeria: Prospects, Challenges and Strategies. Mediterranean Journal of Social Sciences Vol 5 No 2, pp47-55; MCSER Publishing, Rome-Italy E-ISSN 2039-2117 ISSN 2039-9340

[8] Vanguard (2012), JAMB Computer Based Test in 2013: $\begin{array}{lll}\text { Stakeholders } & \text { react. } & \text { November }\end{array}$ www.vanguardngr.com.

[9] Buzzetto-More N. A. and Alade A. J. (2006): Best Practices in e-Assessment, Journal of Information Technology Education Volume 5, pp251-269. University of Maryland Eastern Shore, Princess Anne, MD, USA http://aahe.ital.utexas.edu/electronicportfolios/index.ht $\mathrm{ml}$.

[10] Jim Mauch (2005): Performance Based Assessment vs. Traditional Assessments in the Science Classroom. Retrieved 30/09/2015 from http://www.csun.edu/ jem68622/695b/comps/peforman ceassessment.pdf

[11] Monroe County Intermediate School District (). Three Types of Assessment Retrieved 30/9/2015 from https://www.monroeisd.us/departments/curriculum/instr uctionalservices/assessment/typesofassessment/

[12]H. Ndume, S.I. Dasuki \& P. Ogedebe (2014). EAssessment Systems For Universities In Developing Countries: A Nigerian Perspective. Afr J. of Comp \& ICTs. Vol 7, No. 4. Pp 9-14.

[13]Dietel R. J., Herman J. L., and Knuth R. A. (1991): What Does Research Say About Assessment? NCREL, Oak Brook, retrieved 30, Septenber 2015 from http://methodenpool.uni-
koeln.de/portfolio/What\%20Does\%20Research\%20Say $\% 20$ About\%20Assessment.htm

[14] Oluwatosin T. O. and Durojaye D. S. (2013) ComputerBased Test: Security and Result Integrity. International Journal of Computer and Information Technology (ISSN: 2279-0764) Volume 02-Issue 02, March 2013 